\title{
"There is great unrest": Some Reflections on Emotion and Memory in Julian Barnes's Nothing to Be Frightened Of and The Sense of an Ending
}

\section{Ivan Callus}

This paper responds to the perception that postmodern narratives which are formally complex might be less emotionally involving than other areas of literature. It considers that perception in the context of a discussion of the relation between memory and affect in English literature and culture, referring to stereotypical constructions and counter-constructions of English reserve and of its representation in both canonical and contemporary (and postmodern) English writing. In its argument, the paper refers initially to contrasting concerns arising from the work of critics like Eliot, Richards, Leavis, Edmundson and Belsey but focusing its attention more particularly on Fulian Barnes's memoir Nothing to Be Frightened Of (2008) and his novel The Sense of an Ending (2011). From that scrutiny of Barnes's work, a number of insights emerge into the complex relations between memory, emotion, postmodernism and Englishness.

This paper considers whether there is any incongruity between the ingenious narrative architectures and metafictional sophistication of postmodernist fiction and the prospect of emotion in the raw. Seeking a case-study where an understated manner with poignant matter might prove revealing, it finds Julian Barnes's Nothing to Be Frightened Of (2008) entirely to the purpose: a memoir where stylistic poise in the mediation of remembrance of things past and present sets up intriguing contrasts between equanimity of form and unrest in the content. The tone of elegant wistfulness seems exactly apt for the analysis indicated, and Barnes's The Sense of an Ending, a novel of agitated reminiscence which won the Booker Prize in 2011 and which tellingly ends on that word, unrest, sets up an intriguingly more rounded inquiry. Admittedly, the affinities with postmodern poetics in both texts are a little less evident than in, say, Flaubert's Parrot (1984) or A History of the World in 101/2 Chapters (1989). But the interest, rather and precisely, lies in the representation of very private emotion by an author who had once been more straightforwardly perceivable 
as postmodernist, at least in some ways, and who had always himself had some reputation for being careful about disclosures. As an interviewer put it to him, "Until now, you appeared to agree with Flaubert $[\ldots]$ and never revealed much about yourself" (Guignery and Roberts, 165).

As a preamble, it must be acknowledged that discomfiture before the affective powers of literature bears some scrutiny. Scrutiny was coincidentally the name of the journal that F. R. Leavis edited for many years, between 1932 and 1953, and which with his other writings influenced critical orthodoxy in Britain for a good long spell. Leavis's view in Culture and the Environment (1933), written with Denys Thompson, that "it is to literature alone, where [language's] subtlest and finest use is preserved, that we can look with any hope of keeping in touch with our spiritual tradition" (82) exemplifies what he meant by the moral value of literature. That was not necessarily associated with the discernment of right and wrong, but with the capacity of literature to school and humanize. Preoccupation (where it arises) over the distancing from responses to literature disinvested in that capacity will seem crypto-Leavisite, suggesting nostalgia for the confidence that the great works can "change the possibilities of the art for practitioners and readers", that "they are significant in terms of the human awareness they promote" (Leavis, The Great Tradition, 10). Present-day criticism can indeed seem disaffiliated from literature's presumed capacity to educate moral and emotional response. This is not to suggest that readers (who, as Catherine Belsey reminds us throughout $A$ Future for Criticism (2011), tend not to read academic criticism anyway and are demonstrably alienated from it when they do) are being dissuaded from being affected by the novels they read (an outcome impossible to configure and an objective no theorist will claim). Rather it is to recognize the reluctance to base appreciation or critique on the extent to which one is or is not "spiritually" educated - or moved - by literature. And so, if contemporary fiction were to be found to reflect that reluctance, the trend would not only compel commentary but might suggest that contemporary narrative and its readers had become slightly embarrassed by the human itself. In these post-humanist times, that would be noteworthy. Mark Edmundson, author of Why Read? (2004) and of the influential essay "On the Uses of a Liberal Education" (1997) has much to say about this. Literature, he says, takes you into the realms of "expanded possibility"; he deplores those who "find it embarrassing to talk about poetry as something that can redeem a life", who scorn the idea that literature is "our best goad toward new beginnings, our best chance for what we might call 
secular rebirth" in which the reader "learns the language of herself" and is "humanly enhanced" (Why Read?, 2-4).

W. K. Wimsatt and Monroe C. Beardsley would probably discern openings to affective fallacy there. But the disquiet about responses to literature that disengage from the spiritual or the affirmative or the aesthetic, and that appear to instead assert rhetoric, form or ideology, is expressive of broader concern. The affinities which in many perceptions bind emotion, the human, and the literary are indeed what concern me in this paper, particularly how they are inscribed in contemporary English fiction. Consequently, and in the light of a supposedly restrained investment in emotion in contemporary English fiction, at what point does the affective charge of a novel appear to present-day readers (or students) to risk tipping over into the sentimental? Few readers nowadays will openly wallow in the sentimental, though Sterne's, for instance, would readily have countenanced it, not least because as we know the term meant something rather different then. Instead literature now famously prizes irony and suspects earnestness. It does not do ardency or sentimental journeys in quite the same way. Yet there is ample evidence to be found in contemporary readerships of an undimmed desire to be moved by literature, to discover an infelt response even while remaining critically disinterested.

The difficulty here is that the often remarkable architectonics of postmodernist fiction do not necessarily facilitate empathy with characters' predicaments, mind-sets, and behaviours. Many contemporary novels are ingeniously constructed and fiendishly clever, but they can appear to lack emotional resonance. The daedal design of much contemporary fiction can frequently drive admiration and intellectual curiosity, but not - if this word might be permitted in critical contexts and in what is, perhaps, precisely the point - love. Two examples, Christine Brooke-Rose's Thru (1975) and Georges Perec's La Disparition (1969), may clarify what is under scrutiny. BrookeRose's novel is hardly emotionless, but the bizarrerie of the pages' design distracts involvement through the foregrounding of the radical innovation brought to the very appearance of literary prose. Perec's La Disparition, which contrives to write itself without a single instance of the letter $e$, the most common vowel in French and in English (Gilbert Adair's extraordinary English translation, $A$ Void, pulls off the same trick), is highly charged emotionally, but its lipogrammatic play is less integrative of affect than Leavis's conception of form, say, envisaged, at least on a first encounter. Before novels like this, an outspoken and unsympathetic reaction might be typified by D. J. Enright's 
notorious response to Nabokovian ingenuity: "It's like farting Annie Laurie through a keyhole - it's clever, but is it worth the trouble?" Or, as Tony Webster, the narrator of The Sense of an Ending puts it,

Of course, there were other sorts of literature - theoretical, self-referential, lachrymosely autobiographical - but they were just dry wanks. Real literature was about psychological, emotional and social truth [...]" (15; emphasis added).

It is, clearly, a little more complicated than that. But ambivalence over novels which appear more algorithmic than evocative, more formally than emotionally wrought, will remain. Certainly, the currency even away from the academy of notions like subjectivity, metafiction, ironic revisitation and epistemes of all kinds have not eliminated any desire to react viscerally to literary fiction. That kind of connection typically precedes or even suspends profounder analysis or interpretation. Isn't that, it might be artlessly asked, the point of literary texts: their capacity to suggest that all of life is there, their capacity to provide a slice of life in moving and memorable words, doing so through the poietic incisiveness of forms of language that appears to exist only fitfully in other texts, if at all? This peculiarity of literary language - a language preferentially related to Forster's "education of the heart", to Imagination, to Keatsian negative capability, it would seem - is an inscrutable thing indeed. It continues to mystify and beguile. It almost prompts investigation into how poignancy, humanity, and the literary (or, at any rate, art) are coimplicated.

For I. A. Richards, it is worth recalling, the co-implication arises because literature satisfies an "appetency" for emotive and cognitive equipoise. The idea has admirers and detractors, the latter motivated by uncertainty over whether literature is best justified as some kind of re-equilibrating therapy for the busied soul. T. S. Eliot would be ambivalent, as suggested by his thoughts on "undiscipined squads of emotion" in East Coker, on "the pernicious effects of emotion" (The Sacred Wood, 13), on fervidity unanchored in objective correlatives, and on the impersonality of the artist. Yet Eliot's suspicion of emotion as measure or as disruptive principle in life and art and criticism did not prevent him lamenting the dissociation of sensibility which he regarded as impairing the English literary tradition in the seventeenth century. It prompts speculation that contemporary fiction might be coextensive with a further dissociation of sensibility, one which in criticism shears the intellectual 
response to literature irrevocably away from any emotions-educating vocation. However, this calls for caution. Leavis's, Richards's and Eliot's positions are much more nuanced than the space available here allows me to explore. By the same token, it is a reductive formulation of contemporary fiction that stresses formal ingenuity over imaginative reach and emotional resonance. Nevertheless, the stereotypes will crowd in. It therefore becomes intriguing to reconsider the English literary tradition in the light of those constructions. How does the contemporary English novel represent emotions when one of the signifiers of Englishness remains an upper lip set stiffly, even as the nether one registers a trembling?

Of course, counter-stereotypes are easy to posit. One of them casts the English as a nation overcome by emotional correctness. Ever since the outpouring of public grief at Princess Diana's funeral in September 1997, emotional correctness has formed part of the English mediascape, if not necessarily the more private spaces of the nation. Intriguingly, the English literary tradition itself suggests emotiveness far more readily than restraint. From Chaucer's Prioress, who "wolde wepe, if that she saugh a mous / Kaught in a trappe, if it were deed or bledde", to the despair of Marlowe's Faustus, to the emotionally charged resolutions of Shakespeare's plays, to Johnson's monumental irritability, to Pope's creative spite, to the Lyrical Ballads' vision on the spontaneous overflow of powerful feeling and emotion recollected in tranquillity, to Tennyson's elegiac grief, to Hopkins's alliteratively tortured lines reflecting tortured thoughts, the English poetic and dramatic tradition only problematically upholds the image of English reserve. That, however, is doubtless a function of the lyrical and the theatrical, so that it is not surprising that English prose and the novelistic tradition will appear more complexly swayed in this regard. Consider Burton's Anatomy of Melancholy; the lachrymose cult of sentiment at the end of the eighteenth century, as in Henry Mackenzie's The Man of Feeling (1771); the restraint which shapes Austen's exploration of the tensions between sense and sensibility; the elemental love of Catherine Earnshaw and Heathcliff; the melodrama in some Victorian narrative; the tempestuousness of Lawrence's heroes; the contrast between English frigidity and Italian or Indian ardour in Forster; the rationalizing narration in Conrad or James, whom Leavis thinks of as English; the formfenced intensities in Woolf; the policing of imaginative emotion in Orwell; the resentments of the novels and plays of the Angry Young Men; or, finally, Martin Amis's emblematic protagonist in The Information (1995), a man who needed no alarm clocks, we are told on the first page, because he was already 
"comprehensively alarmed". Throughout, tone and action are affected by very English unease over conflict between the social expectation of what is emotionally appropriate and the eruption of feeling within personal space. Consider too, in popular narrative, the murderous undercurrents that lurk beneath genteel contexts to drive that most English of forms, the whodunit; or the spectrum of emotions in the horror genre as practised by M. R. James or Walter de la Mare; or indeed the observation in P. G. Wodehouse's The Code of the Woosters (1938), familiar to aficionados, which comically captures the perennial English struggle with keeping feelings in check while hinting at their depth: "He spoke with a certain what-is-it in his voice, and I could see that, if not actually disgruntled, he was far from being gruntled" (9). It conveys the English tendency to try to take the edge off emotional intensities while obliquely articulating depths of feeling.

It is Evelyn Waugh's A Handful of Dust (1934), however, which affords the most chilling enactments of the contrast between conflicted emotion and dispassionate prose. Brenda Last is married to Tony Last, a country gentleman who is Englishly decent; she is however having an affair with the arriviste John Beaver. Her young son, John Andrew Last, is out riding one day and dies in an accident. In a well-known episode which bears re-quoting here, the tragic news is brought to her by a friend, Jock Grant-Menzies. Jock discloses the awful truth after a suspenseful build up:

'What is it, Jock. Tell me quickly, I'm scared. It's nothing awful, is it?

'I'm afraid it is. There's been a very serious accident.'

'John?'

'Yes.'

'Dead?'

He nodded.

She sat down on a hard little Empire chair against the wall, perfectly still with her hands folded in her lap, like a small well brought-up child introduced into a room full of grown-ups. She said, 'Tell me what happened. Why do you know about it first?'

'I've been down at Hetton since the weekend.'

'Hetton?'

'Don't you remember? John was going hunting today.'

She frowned, not at once taking in what he was saying. 'John ... John Andrew ... I ... oh, thank God ...' Then she burst into tears. 
There are few more excruciating shocks in fiction than Brenda's unguarded relief that John Beaver is not dead and the belatedness of her confused dread over the death of her son John Andrew. The underplaying demonstrates how represented emotion in literature and emotion evoked in the reader can coincide (or not) in the most unnerving ways. A page later, self-reproach and censure surface in torments of said and unsaid:

'When you first told me,' she said. 'I didn't understand. I didn't know what I was saying.'

'I know.'

'I didn't say anything, did I.'

'You know what you said.'

'Yes, I know ... I didn't mean ... I don't think it's any good trying to explain.'

Jock said, 'Are you sure you've got everything?'

'Yes, that's everything,' she nodded towards the little case on the bed. She looked quite hopeless.

'Well, we'd better go to the station.'

'All right. It's early. But it doesn't matter.'

Jock took her to the train.

$[\ldots]$

'Then I'll say goodbye.'

'Goodbye.' (119-20)

And that, quite clearly, is that. To say more would be bad form.

This raises all kinds of questions. Is not this a picture from a vanished England, surviving only in something like a Julian Fellowes script for a series like Downton Abbey? Although it is hardly a scientific question, it remains instructive to ask what contemporary English writing suggests about the emotive instincts of the English today, for insights into the broader cultural imaginary will surely be captured there. Turning to novelists like Ian McEwan or Julian Barnes helps answer that, as their works are particularly amenable to analysis foregrounding emotion. There is much in McEwan, for instance, that is emotionally unrestrained, putrid even. His novels typically turn on a splitsecond of concentrated, life-changing tragedy or (in)decision that traumatizes ordinary and extraordinary lives. They prod and poke the impossibility of emotional evenness after that. Petr Chalupský is right to suggest that McEwan 
"focuses predominantly $[\ldots]$ on the fragility of intense human emotions", especially as these are overtaken by postmodernity's "ultimate scepticism about the unquestionable dominance of human reason, its awareness of life's fragmentariness and its consequent fragility and vulnerability $[\ldots]$ and the impossibility of understanding our life as a totality of any kind" (122-3). In this respect, and in the context of the conciseness needed here, Barnes provides a useful foil, for the predicaments in his work are often less dramatic, though not thereby less infelt. The rest of this paper, indeed, probes the putative Englishness of the emotive charge in his later work.

Barnes is of course a chronicler of Englishness, not only in England, England (1998) but throughout his work. As Christine Jordis points out in Gens de la Tamise, he comes across as also quintessentially English even when being Francophilic (401-403). Part of that stems from effects of distance. Accordingly, allusions to his chequered personal life are left discreetly limited in this critique, as in most commentaries on his work; affective and intentional fallacies notwithstanding, however, they cannot be entirely avoided, for two reasons. Firstly, they are inevitably germane in a paper on emotion. Hence, in the same way that the distance between the professed and the practised is telling if Leavis was "intemperately observant of slights" (MacKillop 268), so it is striking to sense disparity in projected and infelt emotion in Barnes. This leads to the second point, for Barnes's writing has grown more direct about both extra-diegetic and intra-diegetic emotion. The trend can be seen in both Nothing to Be Frightened Of and The Sense of an Ending. The rest of this paper focuses on the former while referring incidentally to the latter; it will be clearer below why the choice for emphasis in a paper with this title counterintuitively fell on memoir, not fiction, and why, indeed and nevertheless, the conclusion must then privilege The Sense of an Ending.

Nothing to Be Frightened $O f$ is a book dominated by a quite particular emotion, dread. It is about that subject most apt to focus the mind and the emotions, death. And yet this emotion, dread, is throughout conveyed with wry elegance. It is an exquisitely controlled and faultlessly judged performance of contradictorily self-effacing, self-baring emotion: a quite English staging of wistfulness where the balance between surgical reminiscence and deprecating self-knowledge is abetted by the suave irony that drives the narration, and which saves the text from being oppressive. Barnes indeed admitted in interview to a tendency "to deflate the pathos by introducing something comic", and that this is a very strong strand of British literature, from Shakespeare onwards" (Guignery and Roberts, 168-9). Following are some examples of the humour. 
I'm giving as many as four because it is important to remember the place of humour in the English way of dealing with emotion, which deflects and defuses so much and allows for saving misrecognition of the infelt. In the first example, Barnes reports how a young friend of his, a prodigy who would later take his own life, "was reading Wittgenstein at sixteen, and writing poetry which pulsed with ambiguities - double, triple, quadruple, like heart bypasses" (13; there are parallels, there, with Adrian Finn's character in The Sense of an Ending). In the second, he imagines "the fury of the resurrected atheist - that would be something worth seeing" (64). In the third, he reports how his philosopher brother, when he attempted to have a dry run at his deathbed utterance, chose the line "Make sure that Ben [his wife] gets my copy of Bekker's Aristotle", whereupon he had to face up to the fact that his wife found this "insufficiently affectionate" (65). The fourth reports a quip of his mother: "One of my sons writes books I can read but can't understand, and the other writes books I can understand but can't read" (68). No seriousness, clearly, without drollery: almost enough, indeed, to prompt the retort of the intense Adrian Finn in The Sense of an Ending: "I hate the way the English have of not being serious about being serious. I really hate it" (33; emphasis in the original). For throughout and in the midst of all this, death, the "nothing to be frightened of" of the title, comes to seriously haunt and unsettle. It is there, even if not directly invoked, in the book's first sentence: "I do not believe in God, but I miss Him".

We realize, as we read, that this will be a book which has this most reserved of living English writers struggling with a further emotion, or desire, that is hard to even conceive of: the rish to empathize with the dead. Empathy, which is supposed to indicate emotional intelligence more reliably than any other measure, is commendable, of course - but in this context of posthumousness, how would it work? How, indeed can one second guess the emoting of the dead - even in contemporary Britain, which supposedly emotes more correctly now? As Barnes tries to come to terms with the passing away of his parents, and with the disappearance of all the relatives and friends and acquaintances he recalls, the desired empathy starts to ghost itself into the writing when it emerges that the book is in effect conceived in the key of "the past conditional" (6). It is as an attempt to understand what his mother and all the other dead people he remembers "would have wanted". The move becomes more striking because it is played back against the rationalist incredulity of his living brother, with whom Barnes in the book keeps having real and imagined conversations, and who has a quick and curt way with fancy. Hence the following passage, 
for instance, where the ache of bereavement is held at bay by the parallel imminence of imagined emotion and desire:

When our mother was first incapacitated by a stroke, she happily agreed that our granddaughter C. should have the use of her car: the last of a long sequence of Renaults, the marque to which she had maintained a Francophile loyalty for decades. Standing with my brother in the crematorium car park, I was looking out for the familiar French silhouette when my niece arrived at the wheel of her boyfriend R.'s car. I observedmildly, I am sure-'I think Ma would have wanted C. to come in her car.' My brother, just as mildly, took exception to this. He pointed out that there are the wants of the dead, i.e. things which people now dead once wanted; and there are hypothetical wants, i.e. things which people would or might have wanted. 'What Mother would have wanted' was a combination of the two: a hypothetical want of the dead, and therefore highly questionable. 'We can only do what we want,' he explained; to indulge the maternal hypothetical was as irrational as if he were now to pay attention to his own past desires. I proposed in reply that we should try to do what she would have wanted, a) because we have to do something, and that something ... involves choices; and b) because we hope that when we die, others will do what we in our turn would have wanted.

What mother or father "would have wanted": the phrase punctuates the book, together with many others that in self-echoing recurrence exert a shaping force upon the text: "either-or", "let's get this death thing straight", "le reveil mortel", "the wake-up call to mortality", "I knew a nice young girl called Mabel", the difference between "dying in character and dying in caricature", "I think you're my wife", and a particularly important one, "would-yourather". There are other replayed phrasings, but this time from other writers and thinkers, for Nothing to Be Frightened Of is also a compendium of others' thoughts about death and bereavement and mourning, starting from the reporting of Plato's assertion that he did not believe in seeing dead bodies, to Rachmaninov, Flaubert, Turgenev, Daudet, Zola, Edmond de Goncourt, Gide, Shostakovich, Jules Renard, Montaigne, Sir Thomas Browne, Larkin, Arthur Koestler, Dodie Smith, Somerset Maugham, and more. They are complemented by reflections on what Barnes refers to as "the future want of a dead person" or "the want of a future dead person": hence the resonances in phrases like "would you rather" or "would have wanted". The subjunctivity 
of the emotion of the dead, in other words, as much as what is prospected through the past conditional, is what Nothing to Be Frightened Of is about.

Barnes's attempt to deal with the emotions surrounding "the final leavings of my parents' lives" (33) is an example of what he calls "secular shriving" (86). It could have been maudlin, but its intenseness is instead moving. It does raise the question, however, of what it is exactly, for this book is clearly not a novel nor a conventional memoir. Barnes explains:

This is not, by the way, my autobiography. Nor am I in search of my parents. I know that being someone's child involves both a sense of nauseated familiarity and large no-go areas of ignorance - at least if my family is anything to judge by. [...] Part of what I'm doing, which may be unnecessary, is trying to work out how dead they are. [...] Narratively, they survive in the memory, which some trust more than others. (34-35)

The book is, indeed, affiliated to the genre of the memoir: blended reminiscence, essayism, and a light fictionalization that does not distort the essential shape of reported events. But differences emerge, connected to the authorial stance on memory: "My philosopher brother distrusts the essential truth of memories. I distrust the way we colour them in" (29; as will be shown below, this (dis)colouring will drive The Sense of an Ending). This has an evident if inauspicious bearing on the authenticity of recollected emotion. "Memories", says Barnes, "appear to the young brain as exact simulacra, rather than processed or coloured-in versions, of what has happened. Adulthood brings approximation, fluidity and doubt, and we keep that doubt at bay by retelling that familiar story, with pauses and periods of a calculated effect, pretending that the solidity of narration is a proof of truth" (37; again, The Sense of an Ending dramatizes this). Unfortunately, there is unreliability there: "We talk about our memories, but should perhaps talk more about our forgettings" (38). Whereupon emotional sincerity becomes fugitive at best, as its recapturing is conditional upon self-reorientation in its regard and the disingenuousness that arises there, whether deliberately or otherwise.

As the same preoccupations arise in The Sense of an Ending (see below), it is intriguing that Barnes reports indecision on whether to make his book a novel rather than what it is. He reports: "[W]hen asked What the Novel Does, I tend to answer, "It tells beautiful, shapely lies which enclose hard, exact truths"' (78). Our emotions are engaged by those truths. And, fascinatingly for the subject of this paper, Barnes confesses his early doubts about this capacity 
to entrust himself with the handling of emotion in his fiction, and indeed even his capacity, as a student, to understand literature's way with emotion. "How, I asked my tutor", he reports, "could I possibly be expected to have any understanding of, or sensible opinions about, Phèdre when I had only the remotest experience of the volcanic emotions depicted in it? He gave me a wry, donnish smile. 'Well, which one of us can ever say that we have?'” (83)

In all this Nothing to Be Frightened Of is carefully deliberated. Barnes thinks through the crafting of recollected emotion and self-positioning and how to express the associated emotions that emerge from the relation between personality, feeling, desire, and art. "The very art I practise [...] runs counter to the idea of a calm farewell to a thinned self. Whatever the writer's aesthetic from subjective and autobiographical to objective and self-concealing - the self must be strengthened and defined in order to produce the work" (88). It is for this reason that he initially thought he might write the book as fiction, as a way of allaying what he calls the "therapeuto-autobiographical fallacy" (97), and placate the very kind of appetency we saw I.A. Richards considering - it is why, indeed, Hilary Spurling's report in The Guardian that Barnes buries his feelings in this book as well as his parents does not do it justice.

Barnes admits that he thought he might have "Just enough time, and just enough lucidity, to write that last book - the one which would contain all my thoughts about death. [...] I didn't know if it was going to be fiction or non-fiction" (100). In the end, the text ends up being non-fictional, though Barnes keeps worrying at its fictional if not quite novelistic qualities:

Lessing described history as putting accidents in order, and a human life strikes me as a reduced version of this, a span of consciousness during which certain things happen, some predictable, others not, where certain patterns repeat themselves, where the operations of chance and what we may as well call free will interact $[\ldots]$ But this does not in my book constitute a narrative. Or, to adjust, it may be a narrative, but it doesn't feel like one to me. [...] And so it is with our lives: one damn thing after another, a gutter replaced, a washing machine fixed - rather than a story. Life is neither long nor short, it merely has longueurs. (189)

Barnes, it seems, concluded that for his most keenly felt book the genre of the novel might not serve. Clearly, however, he himself remains worried by the implication. He keeps going back to it. Most of all, he goes back to it when he is dealing with things for which he does not have, or cannot find, 
the answer. "What you can't find out, and where that leaves you, is where the novelist starts", he says (238). But he is also impatient, it seems, with fiction's compulsion to order the chaotic diversity of life within one coordinated overarching movement:

Fiction is produced by a process which combines total freedom and utter control, which balances precise observation with the free play of the imagination, which uses lies to tell the truth and truth to tell lies. It is both centripetal and centrifugal. It wants to tell all stories, in all their contrariness, contradiction and irresolvability; at the same time it wants to tell the one true story, the one that smelts and refines and resolves all the other stories. (241)

We come to suspect that the story Barnes novels' have struggled to tell is the one in this book, Nothing to Be Frightened of, where he discovers that the story he wanted to tell was one too difficult for the novel form.

And yet - is it? Here are a few reflections on that. Barnes's Nothing to Be Frightened Of helps to reorient consideration of the representation of emotion in the contemporary English novel. I find myself getting back to the question of why such a supremely gifted and controlled novelist chose to write arguably his greatest and most infelt book beyond the novel's poetics, adopting and indeed foregrounding and commenting on many of its conventions as he deploys them, but ultimately being careful to do nothing in his text that would affiliate it to that genre. It would not do to be coy about the fact that the book is moving, involving, affecting, poignant, tragic. Nothing to Be Frightened Of is, in the best sense, sentimental: the sense defined by Barnes himself as existing where "[s]entimentality [...] doesn't come off: when it does, you get a true expression of life's sorrow" (Guignery and Roberts, 168). Perhaps, paradoxically, only a novelist could have written this non-novel; perhaps, indeed, only an English novelist could have written it, full of the tension between reach and obliquity, guardedness and self-revelation. Perhaps such demonstrations of emotion, though they might be supremely un-English, are, in this textual mode at least, supremely, wonderfully, incorrigibly English.

But Nothing to Be Frightened Of is not the completed story, for The Sense of an Ending follows hard upon it. Fiction follows memoir. The novel is re-affirmed. There is, indeed, the Man Booker Prize to show for it. Closure, it would seem, has occurred in more than one sense. The titles and trajectory of these two texts suggest it, too. The Sense of an Ending offers a fictive, displaced re-exploration 
of some of the themes, particularly turning on the nature and operation of memory, which Nothing to Be Frightened Of had explored. Here, indeed, is a novel of "beautiful, shapely lies" sundered by the excavation of "hard, exact truths". Tony Webster, the narrator, tries to reconstruct in his mind situations relating to his past lives and loves; he also revisits places where they were played out. In the context of this paper's focus on emotion, there is a piquant relation to the tumultuous feeling he reports upon because he himself is, in his word, "peaceable". Note the following exchange with Veronica Ford, the enigmatic young woman he was seeing in an earlier life, but who he will split up from to discover later that she has taken up with Adrian Finn, his intense philosophy-loving schoolfriend who will go on to commit suicide at an early age. The quest to discover the truth behind the circumstances around all that provide the narrative thrust to the text:

'You're quite cowardly, aren't you, Tony?'

'I think it's more that I am ... peaceable.'

'Well, I wouldn't want to disturb your self-image.' (35)

The story of The Sense of an Ending is the story of that self-image collapsing, as the peaceable Tony Webster discovers that he has unwittingly and not so unwittingly had a hand in precipitating various tragic events in the lives of those surrounding him. The events occur because a curse idly written in a moment of high emotion in his younger days appears to have had its effect, and because " $[\mathrm{t}]$ he fact that young me who cursed and the old me who witnessed the curse's outcome had quite different feelings $[\ldots]$ was monstrously irrelevant" (138). How to do things with words - indeed. In the process, the contrast is again between poised, equable prose on the surface and deep, conflicted emotion below. For Tony, the trajectory is one of acceptance that even when considering "approaching death" when young, "What you fail to do is look ahead, and then imagine yourself looking back from that future point. Learning the new emotions that time brings" (59). Memory and emotion are clearly co-implicated here. Tony's predicament is that he finds himself forced to acknowledge that what he had remembered about key events in his life around which he had constructed his entire personal and emotive bearings had been, in fact, distorted. He must rebuild self-narrative and self-recollection until self(mis)recognition is almost irredeemably devastating. Learning new emotions always is. "Memory equals events plus time", Tony remarks, and the tenses of the temporalities conjugating that learning and articulating that whole, like 
the past conditional or the future anterior, will always be discovered to have been deconstituting, positioning the self one would rather have been and the subjectivity one will have found oneself only marginally co-determining. Tony becomes increasingly aware that he can only speak of a personal history that is "deliquescent" (6o), that "the only evidence comes from my memory" (39), from "my memory now of my reading [of events] then" (41), so that he, who had earlier commented that "as the witnesses to your life diminish, there is less corroboration, and therefore less certainty, as to what you are or have been" (59), must accommodate the "unwelcome corroboration of what I was, or had been" (103), not least as testimonies to his earlier being, and actions, come irrepressibly to notice and re-memory. Key to all this is that as that happens, so one's affective constitution changes. "[W] hat if, even at a late stage, your emotions relating to those long-ago events and people change?" (120), he asks himself. Peaceable existence, emotive equipoise, thereby shatters, however English the tone of the recollection is. "I had completely failed to pick the tone", Tony reflects at one stage (130), and it is hard not to think that it is not the tone of the conversation in question that he has mistaken, but of the conduct of a life entire, which now must be recollected differently, with only "remorse for company" (140).

Towards the end of the novel, then, Tony discovers that the desire that emotions "will support your life as it is and as it has become" (110) is unfulfilled. Life is "accumulation" and "responsibility", as the last paragraph spells out, and "beyond these there is unrest. There is great unrest"(150). This ending, the sense that emotions will break through and undo even the expectations of the self-deludedly peaceable, is what this English novel - perhaps the English novel generally, as Leavis might have added - leaves us with. Perhaps it did not take a contemporary English novel to teach us that, but whatever the demographics of fiction and the postmodern affiliations involved there, we are left with one reflection: namely, that there is nothing to be frightened of more than the re-learnt emotions at, and of, the end, where what remains is the unrest of the peaceable.

\section{Works Cited}

Amis, Martin. The Information. London: Flamingo, 1995.

Chalupský, Petr. The Postmodern City of Dreadful Night: The image of the city in the works of Martin Amis and Ian McEwan. Saarbrücken: VDM Verlag Dr. Muller, 2009.

Barnes, Julian. Flaubert's Parrot. London: Jonathan Cape, 1984. 
Barnes, Julian. A History of the World in 101/2 Chapters. London: Jonathan Cape, 1989 .

Barnes, Julian. England, England. London: Jonathan Cape, 1998.

Barnes, Julian. Nothing To Be Frightened Of. London: Jonathan Cape, 2008.

Barnes, Julian. The Sense of an Ending. London: Jonathan Cape, 2011.

Belsey, Catherine. A Future for Criticism. Oxford: Wiley-Blackwell. 2011.

Brooke-Rose, Christine. Thru. London: Hamilton, 1975.

Edmundson, Mark. "On the Uses of a Liberal Education." Harper's Magazine, September 1997 39-49.

Edmundson, Mark. Why Read? New York: Bloomsbury, 2004.

Eliot, T. S. The Sacred Wood. 1920. London: Methuen, 1960.

Enright, D. J. "Nabokov's Way." The Nerw York Review of Books, 3 Nov 1966: 3-4.

Guignery, Vanessa, and Ryan Roberts. "Julian Barnes: The Final Interview." Conversations with fulian Barnes. Ed. Vanessa Guignery and Ryan Roberts. Jackson: University Press of Mississippi, 2009. 161-88.

Jordis, Christine. Gens de la Tamise: Le roman anglais au XXe siècle. Paris: Seuil, 1999 .

Leavis, F. R. The Great Tradition. 1948. Harmondsworth: Penguin, 1962.

Leavis, F. R., and Denys Thompson. The Training of Critical Awareness. London: Chatto \& Windus, 1933.

Perec, Georges. La Disparition. Paris: Gallimard, 1969.

Perec, Georges. A Void. 1969. Trans. Gilbert Adair. London: The Harvill Press, 1995 .

Richards, I. A. Principles of Literary Criticism. 1924. Ed. John Constable. New York and London: Routledge, 2001.

Spurling, Hilary. "Colder but Wiser." The Guardian. 2 March 2008. Review, 8. Waugh, Evelyn. A Handful of Dust. 1934. Harmondsworth, Penguin, 1973.

Wimsatt, W. K and Monroe Beardsley. "The Affective Fallacy." Sewanee Review 57. 1 (1949): 31-55.

Wodehouse, P. G. The Code of the Woosters. London: Herbert Jenkins, 1938. 